\title{
RANCANG BANGUN TURBIN PELTON MIKROHIDRO
}

\author{
Maridjo, Bambang Puguh, Slameto, Budi Suharto, Abdulrahman \\ Jurusan Teknik Konversi Energi, Politeknik Negeri Bandung \\ Jalan geger kalong Hilir, Ciwaruga, Bandung \\ Email : mmaridjo@gmail.com
}

\begin{abstract}
Abstraksi
Pembangkit listrik tenaga air skala kecil, saat ini banyak dikembangkan di Negara berkembang, baik skala minihidro, mikro maupun picohidro. Saat ini pembangunan tenaga air skala kecil yang termasuk kelompok energi terbarukan lagi gencar dikembangkan di Indonesia. Pembangunan pusat tenaga air skala kecil ini dibuat untuk memenuhi kebutuhan energi listrik di pedesaan yang belum ada jaringan listrik dari PLN. Penelitian ini ditujukan untuk mengkaji pembuatan dari desain, pembuatan, pemasangan, pengoperasian dan pengujian pembangkit tenaga listrik skala kecil jenis picohidro Pelton. Jenis turbin yang di buat dan diuji jenis turbin pelton sudu mangkok, turbin ini dirancang dengan kapasitas debit 4 liter/detik dan head 5 meter yang menghasilkan turbin pelton dengan sudu 17 buah, diameter runner $27 \mathrm{~cm}$, dan diameter nosel $20 \mathrm{~mm}$. Turbin pelton, diuji dengan variasi beban untuk bukaan katup tertentu untuk mengetahui kinerja turbin. Adapun hasil pengujian turbin pelton untuk bukaan katup pemuh adalah 41,38 watt pada putaran $458 \mathrm{rpm}$ dan menghasilkan efisiensi turbin sebesar $24,81 \%$
\end{abstract}

Kata Kunci : Turbin Pelton mikro, Efisiensi

\section{PENDAHULUAN}

Banyak Negara menyadari pentingnya pemanfaatan sumber energi terbarukan sebagai pengganti energi tidak terbarukan seperti minyak bumi, batubara yang telah menimbulkan dampak yang merusak terhadap bumi. Dengan semakin menipisnya cadangan energi tidak terbarukan, maka harganya akan semakin meningkat. Pada saat yang sama energi tidak terbarukan akan melepas emisi karbon yang dapat menyebabkan pemanasan global.

Di Indonesia, masih banyak daerah pedalaman yang belum dilewati jaringan PLN. Daerah pedalaman ini menjadi tempat yang terisolasi dan bergantung pada pemakaian energi tradisional yang tidak dapat diandalkan. Energi terbarukan menjadi solusi praktis terhadap kebutuhan energi di pedesaan dan dapat mudah diimplementasikan.

Banyak alasan mengapa energi terbarukan menjadi pilihan, diantaranya: tersedia secara melimpah; tidak akan habis; relatif tidak mahal; mudah implementasinya; ramah lingkungan, tidak menimbulkan polusi; tidak memerlukan perawatan yang komplek dan dapat memberikan peluang kemandirian kepada masyarakat pedesaan.

Energi tenaga air merupakan salah satu energi terbarukan [1]. Energi air merupakan sumber energi yang ramah lingkungan. Aliran air diarahkan untuk menggerakkan turbin yang akan menghasilkan energi listrik yang disebut energi tenaga air. Energi tenaga air mengubah energi potensial yang terdapat didalam air. Aliran air yang mengandung energi potensial ini selanjutnya dialirkan ke turbin yang dikopel dengan generator dan akan menghasilkan energi listrik. Jenis tenaga air ini digolongkan berdasarkan head (ketinggian jatuh air), kapasitas, desain dan jaringan dayanya.

Indonesia sangat cocok memanfaatkan tenaga air, mengingat potensinya sangat besar. Banyak pedesaan Indonesia yang belum terjangkau jaringan listrik dan memiliki potensi tenaga air, sangat cocok dibangun mikrohidro atau picohidro [2]. Pembangkit listrik mikrohidro dapat mengurangi emisi bahan bakar fosil. Pembangkit mikrohidro menggunakan sumber daya energi terbarukan yang gratis, tidak ada limbah. Pembangkit energi listrik 
mikrohidro dapat menyuplai listrik tanpa mempengaruhi kualitas air.

Pada rancang bangun simulasi pembangkit listrik picohidro dipilih jenis turbin Pelton. Turbin Pelton ini merupakan turbin aksi atau impuls. Turbin Pelton terdiri dari satu set mangkok yang diputar oleh pancaran air yang disemprotkan dari satu atau lebih alat yang disebut nosel

\section{METODOLOGI}

Tahapan rancangan

Dalam melakukan rancang bangun, tahapan yang dilakukan sebagai berikut :

1. Perancangan

Tahap ini terdiri dari beberapa kegiatan diantaranya perancangan untuk menentukan dimensi turbin, pemilihan bahan, dan membuat gambar kerja sesuai dimensi yang telah ditentukan.

2. Pembuatan peralatan simulasi pembangkit listrik

Tahap pembuatan komponen turbin sesuai hasil rancangan dan dilanjutkan dengan perakitan sehingga sistem pembangkit listrik terbangun.

3. Pengujian peralatan

Pengujian yang akan dilakukan adalah pengujian dari fungsi komponen dan kinerja peralatan, metode yang dipilh yaitu dengan variasi beban untuk bukaan katup tertentu.

\section{PerancanganTurbin Pelton}

Perhitungan rancangan dapat dihitung menggunakan persamaan berikut [2][3] :

Nosel, mangkok dan runner turbin :

1) Kecepatan pancaran air keluar nozel

$$
C_{1}=k c \times \sqrt{2 \times g \times H}
$$

$(\mathrm{kc}=$ KoefisienNozel $=0.96-0.98)$

Dimana :

$\mathrm{g}$ - gravitasi (m/det2)

$\mathrm{H}$ - head /tinggi tekan (m)

2) KecepatanKeliling runner

$$
U=k u \times \sqrt{2 \times g \times H}
$$

$\mathrm{Ku}=$ koefisien $=0,45$

3) Persamaaan Daya

$$
P_{\text {hidrolik }}=\rho g Q H
$$

$\rho$ - density

$\mathrm{Q}$ - laju aliran

4) Diameter Nozel

$$
d_{n}=\sqrt{4 \times Q_{/ \pi \times C 1}}
$$

5)

Diameter Runner

$\mathrm{n}$ - putaran

$$
D_{\text {run }}=\frac{60 \times U \times i}{\pi \times n_{\text {sinkron }}}
$$

6) JumlahBucket

$$
Z=\frac{\pi \times D}{2 \times d}
$$

7) Dimensi Bucket/mangkok

- Lebar rmangkok

$$
b=3.2 \times d_{n}
$$

- Kedalaman mangkok

$$
t=0.9 \times d_{n}
$$

- Lebar bukaan mangkok

$$
a=1.2 \times d_{n}
$$

- Panjangmangkok

$$
h=2.7 \times d_{n}
$$

\section{Perancangan PorosTurbin}

Perancangan diameter poros turbin menggunakan persamaan sebagai berikut [5]:

1) Daya yang akan diterima oleh turbin

$$
P_{d}=f_{c} \times P_{\text {turbin }}
$$

$f_{c}$ adalah factor koreksi daya yang akan ditransmisikan, adapun nilai $f_{c}$ sendiri diambil dari koefisien tergantung nilai daya yang di trasnmisikan.

2) Momen punter maksimal.

$$
T=\left(9.74 \times 10^{5}\right) \times \frac{P_{d}}{n_{\text {sinkron }}}
$$

3) Tegangan geser maksimal.

$$
\tau_{a}=\frac{\sigma_{B}}{S_{f 1} \times S_{f 2}}
$$

4) Diameter Poros

$$
D_{p}=\left[\frac{5.1}{\tau_{a}} \times K_{t} \times C_{b} \times T\right]^{\frac{1}{3}}
$$


Tabel 1. Hasil rancangan

\begin{tabular}{|l|l|}
\hline Kecepatan pancaran air keluar nosel & $9.6 \mathrm{~m} / \mathrm{s}$ \\
Kecepatan Keliling runner & $4.55 \mathrm{~m} / \mathrm{s}$ \\
Diameter Nozel & $20 \mathrm{~mm}$ \\
Jumlah Mangkok & $22 \mathrm{~cm}$ \\
Dimensi Sudu & 17 \\
Lebar Mangkok (b) & $5 \mathrm{~cm}$ \\
Tinggi Mangkok (h) & $4.2 \mathrm{~cm}$ \\
Kedalaman Mangkok (c) & $1.8 \mathrm{~cm}$ \\
\hline Delonggaran Cetakan Mangkok (k) & $2.4 \mathrm{~cm}$ \\
\hline Diameter Luar Runner (Do) & $2.2 \mathrm{~cm}$ \\
\hline
\end{tabular}

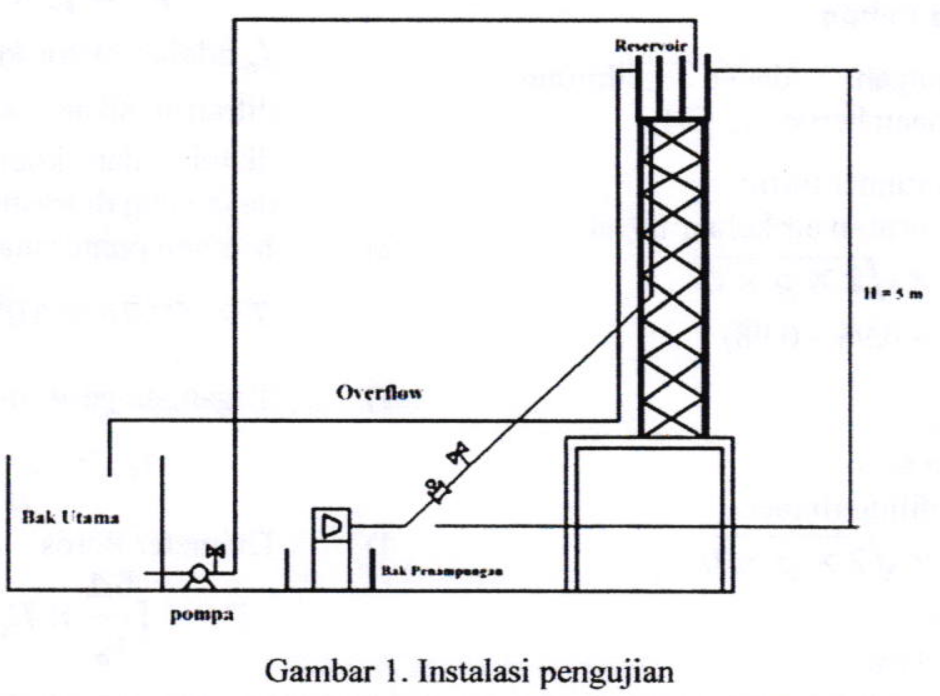




\section{HASIL DAN PEMBAHASAN}

\section{Hasil rancangan}

Hasil rancangan berdasarkan asumsi debit air yang tersedia, head dan putaran generator sebagai berikut :

- Debit air yang akan digunakan untuk masuk ke turbin

$$
(\mathrm{Q}) \approx \quad 0.004 \mathrm{~m}^{3} / \text { detilk }
$$

- $\mathrm{Head}=5$ meter

- Asumsi putaran generator adalah $400 \mathrm{rpm}$

\section{Pengujian dan hasil}

Untuk mengetahui kinerja dari turbin yang dibuat maka dilakukan pengujian. Metode pengujian dengan kondisi variasi beban pada bukaan katup tertentu. Instalasi pengujian seperti gambar 1.

Hasil pengujian turbin pelton sudu mangkok dengan Head 5 meter, Debit maksimal 3,4 liter/detik, menggunakan 1 buah nozle dan diuji dengan variasi beban pada bukaan katup 50\% dan $100 \%$ adalah sebagai berikut:

\section{Hubungan Antara Bukaan katup dan Putaran}

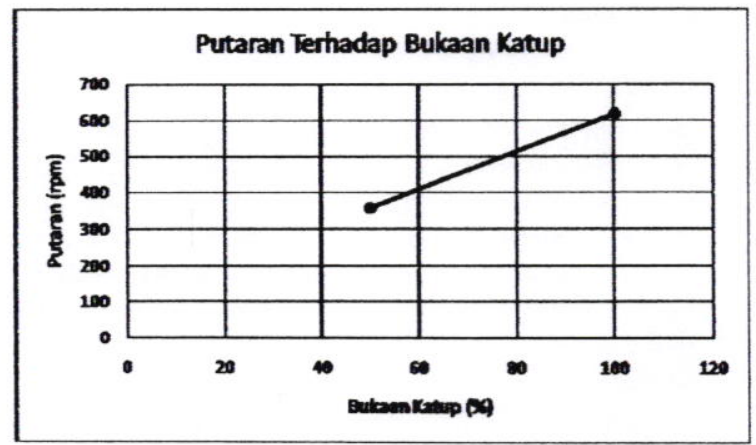

Gambar 2. Grafik putaran terhadap bukaan katup

Dari grafik dapat disimpulkan bahwa semakin besar bukaan katup maka semakin tinggi pula putaran turbinnya. Hal ini disebabkan oleh debit air yang keluar semakin besar karena semakin besar bukaan katup. Debit air yang lebih besar akan memberikan dorongan yang lebih kuat terhadap sudu-sudu turbin sehingga putaran turbin semakin cepat. Pada grafik didapat putaran tertinggi adalah $618 \mathrm{rpm}$ pada bukaan katup $100 \%$.

\section{Hubungan Antara Putaran dan Torsi}

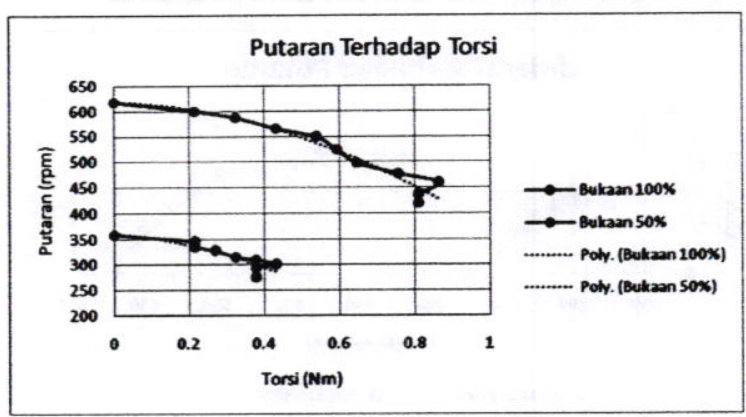

Gambar 3. Grafik putaran terhadap torsi

Bisa dilihat pada grafik bahwa semakin besar torsi maka putaran akan semakin turun. Hal ini disebabkan oleh beban yang diberikan semakin besar dan membuat putaran turbin menurun. Pada grafik didapat torsi terbesar yaitu pada bukaan katup $100 \%$ dengan Torsi $0,86 \mathrm{Nm}$ pada putaran $458 \mathrm{rpm}$.

\section{Hubungan Antara Putaran dan Daya Poros}

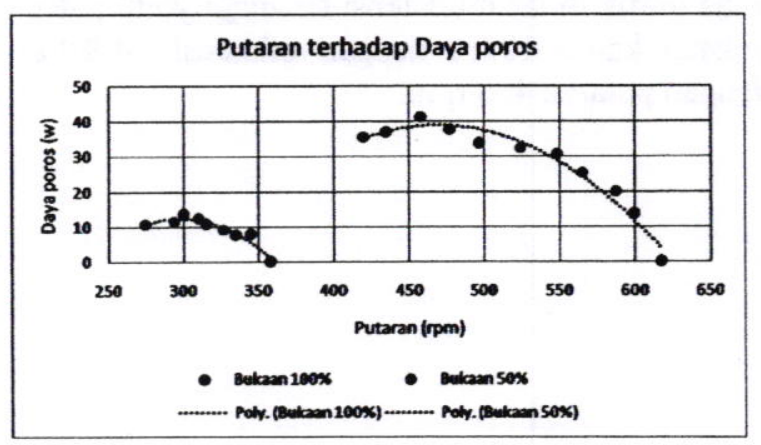

Gambar 4. Grafik putaran terhadap daya poros

Bisa dilihat pada grafik bahwa daya poros akan semakin naik jika putaran turbin turun hal ini akibatkan karena pembebanan dari tanpa beban hingga beban $13,5 \mathrm{~kg}$ dan setelah mencapai titik optimum daya menurun. Pada Grafik saat bukaan $50 \%$ daya maksimum yang dihasilkan adalah 13,55 watt pada putaran $300 \mathrm{rpm}$ sedangkan saat bukaan katup $100 \%$ daya maksimum yang dihasilkan adalah 41,38 watt 
pada putaran $458 \mathrm{rpm}$, daya yang dihasilkan tergantung dari torsi dan putaran, semakin besar torsi semakin rendah putarannya, begitu juga sebaliknya.

\section{Hubungan Antara Putaran dan Efisiensi}

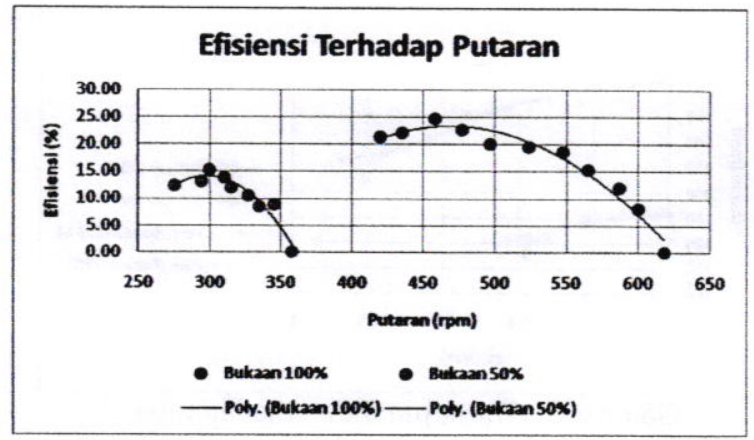

Gambar 5. Grafik Efisiensi terhadap putaran

Grafik diatas merupakan hubungan antara efisiensi terhadap putaran turbin (rpm). Bisa dilihat pada grafik bahwa efisiensi turbin terbesar pada putaran tertentu. Hal ini disebabkan karena beban yang tinggi akan mempengaruhi putaran dan efisiensi, beban yang tinggi akan menurunkan putaran turbin dan menaikkan efisiensi pada aliran air tertentu. Pada grafik didapat efisiensi tertinggi yaitu pada bukaan katup $100 \%$ dengan efisiensi $24,81 \%$ dengan putaran $458 \mathrm{rpm}$.

\section{KESIMPULAN}

Turbin Pelton hasil rancangan mempunyai sudu 17 buah, diameter runner $27 \mathrm{~cm}$, dan diameter nosel $20 \mathrm{~mm}$. Hasil pengujian turbin pelton untuk bukaan katup penuh adalah 41,38 watt pada putaran $458 \mathrm{rpm}$ dan menghasilkan efisiensi turbin sebesar $24,81 \%$.

\section{DAFTAR PUSTAKA}

[1.] Imam Kholiq, "Pemanfaatan Energi Alternatif Sebagai Energi Terbarukan Untuk Mendukung Subtitusi Bbm", Jurnal IPTEK Vol.19 No. 2, Desember 2015, ISSN: 1411-7010, e-ISSN: 2477-507X

[2.] Made Suarda, "Kajian Teknis dan Ekonomis Potensi Pembangkit Listrik Tenaga Mikro-Hidro di Bali", Jurnal Ilmiah Teknik Mesin, CakraM Vol. 3 No.2. Oktober 2009 (184-193)

[3.] M. Edy Sunarto, Markus Eisenring. 1994. "Turbin Pelton Mikro“, Yogyakarta: MHPG ANDI OFFSET.

[4.] Abdulrahman, Maridjo, "Pembuatan Turbin Pelton"

[5.] Sularso, "Dasar Perencanaan dan pemilihan Elemen Mesin", Pradnya Paramita, 1987 